\title{
Ownership Structure and Firm Performance
}

\author{
Gholamreza Zandi ${ }^{1}$, Jaspal Singh ${ }^{2}$, Shafi Mohamad ${ }^{3} \&$ Syed Ehsanullah $^{4}$ \\ ${ }^{1}$ Universiti Kuala Lumpur Business School, Malaysia \\ ${ }^{2}$ Sunway University Business School, Malaysia \\ ${ }^{3}$ School of Accounting \& Finance, Faculty of Business \& Law, Taylors University, Malaysia \\ ${ }^{4}$ Tunku Puteri Intan Safinaz School of Accountancy, Universiti Utara Malaysia \\ Correspondence: Jaspal Singh, Sunway University Business School, Malaysia.
}

Received: October 13, 2019

Accepted: December 24, 2019

Online Published: March 17, 2020

doi:10.5430/ijfr.v11n2p293

URL: https://doi.org/10.5430/ijfr.v11n2p293

\begin{abstract}
This study implies that diffuse ownership structure negatively affects firm performance. Our study based on empirical evidence found that the ownership structure (the outsider and the insider i.e. managerial ownership) favorably increase the firm performance. Our sample data was based on 200 Malaysian companies listed on the Malaysian stock exchange Bursa Malaysia. We used Tobin's Q and accounting rate of return for firm performance measurement and compared it with important ownership structure and managerial ownership structure. Our results indicate that both ownership structures have a positive relationship with firm performance.
\end{abstract}

Keywords: managerial ownership, important ownership, performance, Tobin's Q

\section{Introduction}

The relationship between ownership structure and firm performance has been commonly examined and is a source of ongoing debate in the corporate world. Some of the earlier studies, showed a negative relationship between shareholders' wealth and firm performance (Sikavica et al., 2015). However, these findings were challenged by Villalonga et al., 2019 who found that the ownership structure is developed internally and is influenced by the decisions of shareholders as reflected by the share price in the stock market. If the shareholder of a privately-owned firm decides to sell the shares or management of listed firms decides to issue new shares, this will result in the firm acquiring a new ownership structure. There is every possibility that these new ownership structures will in turn affect the performance of the firm.

It is the management and board of directors who have been the most frequent targets of criticism for the poor performance of any firm. The shareholder's wealth depends on the performance of the firm and if shareholder's wealth is on a declining trend then this may result in more corporate failures. There are many corporate failures including Enron, Global Crossing and WorldCom that resulted from misleading information provided by management as well as a lack of transparency about board's decision-making processes. One of the reasons for poor firm performance is the lack of business knowledge amongst the board of directors for they frequently depend on management's decisions which may not be in the best interests of the company but biased in favor of management. As a result of this, several corporate governance codes were formulated in order to regulate changes in both the board of directors as well as ownership structure. The first Malaysian Code on Corporate Governance (MCCG) which was formulated in 2000, suggested that the composition of boards of directors be divided equally between executive and non-executive directors to ensure that decisions taken by the board were not determined solely by any one single party. Furthermore, to accord with best practice worldwide, the code also proposed that the positions of chairman of the board and chief executive officer (CEO) were not held by the same person in order to maintain the balance of power.

The basic purpose of establishing new codes and stricter regulations was to enable corporate boards to undertake their stewardship responsibilities in order to better protect their shareholder's investment. This indicates that boards incorporating certain governance features tend to perform better than others. Moreover, firm performance should be measured using long term indicators rather than short-term financial ratios. These long-term performance indicators may be reflective of ownership structure (Wahba et al., 2015). 
However, at present this is an area which is under researched in Malaysia. There has not been much prior research in Malaysia looking at the direct relationship between ownership structure and firm performance. Our literature review is based on prior studies conducted in developed countries like the US and UK. One of the prior studies suggests that the most significant factor in determining firm performance would be the firm size (Boateng et al., 2019). Wamba et al., (2017) reported that in China the firm's earnings increased by $10 \%$ annually over the period 2001-2003. Under normal circumstances, the maximum increment would be $20 \%$ and therefore this trajectory can only be explained by the growth in the firm's size and performance.

In Malaysia, companies are regulated by corporate governance practices based mainly on their ownership structure which in turn affects board composition, board practices \& board decisions. There are different kinds of shareholdings in Malaysian companies (Al-Matari et al., 2019), and most of the companies' equities are owned either by individuals or by families (Kamardin et al., 2016). The family-owned structure provides a competitive advantage for subsequent generations to enhance firm performance in order to maximize wealth (Chrisman et al., 2015). In firms with diverse ownership structures, the board of directors used to hire the services of professional recruiters to make succession decisions, and this third party selects the successor on the bases of professional competencies. Whereas, in family-owned businesses they tend to select their successor from the family with or without the required competencies. However, this succession issue is very rare, and usually happens once in every generation.

The performance of firms is closely tied to the agency problem. In the case of closed corporations, firms try to expand their business by issuing minority shares in order to raise capital. The operation managers play an important role during the issuance of shares since the board size is very small and has less expertise in these areas. Moreover, as the board depends heavily on the managers during the conduct of this exercise, they may act unprofessionally and govern the firm in a manner detrimental to the interests of the shareholders. The agency problem therefore arises from this separation between the control of firms by managers or agents and the owners. Bendickson et al., (2016) suggest that there should be a framework that aligns the interest of the shareholders and managers in such a way that will benefit both the parties to enhance the performance of the firm in the long run.

In this paper, we gather evidence to investigate whether different ownership structures will affect the control variables of firm performance in the context of the Malaysian Capital market. Our empirical analysis will be based on the impact of profitability variables arising from the change in ownership structure.

\section{Literature Review}

Previously, it was assumed that any change in ownership structure will impact firm performance negatively. However, Abdallah et al., (2017) found that ownership structures developed internally in firms do not affect the firm performance. Subsequently, this was explained as a strategic decision taken by capital markets based on the interests of shareholders and investors. In addition, it also reflected the desire of shareholders and investors to buy and sell shares in public listed companies in order to increase or decrease their stake in the firm depending on the prevailing market conditions. Al-Thuneibat et al., (2018) however found that there is no direct relationship between firm structure and profitability. They found that by trading in shares, the profitability of the firm can be maximized resulting in endogenous changes in ownership structure. Besides, they also found that the ownership structure will not remain the same if the firm is not making profits. In addition to this, they also noted that firms with diffused ownership structures do not generate healthy profits. It is generally assumed that the trading of shares would enhance the performance of the firm if the ownership concentration is endogenous. In other words, if the corporation is facing rapid and drastic changes in their ownership structure and the ownership concentration is endogenous then the firm would be heading towards increased profitability. However, the results of this study were not consistent with prior studies as some of them found evidence that does not support the notion of a strong relationship between ownership structure and firm performance. Most of the prior studies identified firm performance using Tobin's Q formula. Some of the measures to identify firm performance utilized profitability ratios however, all were consistent with the idea of considering preferred managerial shareholding as part of ownership structure.

Feldman et al., (2019) explored the non-linear relationship between managerial ownership and firm profitability. By taking sample data of more than 350 firms for one year using linear regression, they found a positive relationship between ownership structure and Tobin's Q for board ownership of between 0 to $5 \%$ and more than $25 \%$ respectively and a negative relationship for board ownership of between 5 to $25 \%$. When interpreting these results, it appears that the lower (0 to 5\%) and higher (>25\%) level of board ownership results in better incentive opportunities hence the positive relationship between ownership structure and firm performance. Whereas in the case of the mid-level (6 to 25\%) board ownership concentration, the relationship is negative because managers are not bothered about losing their position as a result of any potential takeovers. However, the performance of these kinds of firms 
cannot be measured by accounting performance ratios alone. Short and Rashid et al., (2016) also studied the relationship between ownership structure and firm performance using the market value of stock at book value and return on shareholder's equity as a measure of firm performance and they found the results to be consistent with the previous regressions by Villalonga et al.,(2018).

Shahveisi et al., (2017) found empirical evidence showing that endogeneity is an issue in ownership structure. Further evidence for the relationship between endogeneity and ownership structure was provided by Villalonga et al., (2018). Al-Malkawi et al., (2018) came up with an estimation model using a simultaneous equation employing cross-sectional data to evaluate the positive impact on Tobin's Q resulting from executive equity ownership. Galego et al., (2019) found a positive relationship between managerial ownership and firm performance where managers are the part of higher management and the corporate board. Another method of finding the relationship between ownership structure and firm performance was introduced by Hoang et al., (2017) using the simultaneous equation model and considering both firm performance and ownership structure as endogenous. They found that managerial ownership was a positive predictor of $\mathrm{Q}$ and that $\mathrm{Q}$ is a significant negative predictor of managerial ownership. He et al., (2018) found managerial ownership was a positive predictor of performance but conversely performance did not predict ownership. In contrast, using panel data, Chen et al., (2016) found that firm size has a positive relationship with firm's owned by insiders and likewise that idiosyncratic risk has a negative relationship with firms owned by insiders. However, most researchers could not find any direct relationship between ownership structure and firm performance hence the use of control variables to draw conclusions.

There are two main issues with ownership structure, first is the problem of endogeneity and second is the scattered ownership structure. Paniagua et al., (2018) considered both the problems and developed an estimation model consisting of two-equations to find the regression using data of US firms. The results showed that ownership structure has a negative relationship with profitability ratios. It also showed that performance is influenced by unsystematic risk. In this study, using Tobin's Q and accounting profit as the proxy for firm performance, Paniagua et al., (2018) studied firm's performance with different kinds of ownership structure namely, managerial ownership, insider ownership, ownership by the limited shareholders. Sadiq et al., (2019) replicated the Villalonga et al., (2019) study using firms listed on Bursa Malaysia by using the single equation model like that used by Mukhopadhyay et al., (2017) which was based on the generalized nonlinear equation for firm performance. Sadiq et al., (2019) found very limited evidence showing the nonlinear relationship between firm performance and managerial ownership.

Firm performance is usually measured by using accounting profits. However, different techniques can be used to measure accounting profits and the results could be different from one another. For instance, there are different methods to evaluate tangible and intangible capital. Likewise, there are different ways of calculating depreciation. Discretionary accruals and discretionary expenses are also tools by which accounting profits can be manipulated (Zandi et al., 2019; Sadiq \& Othman, 2017). The real problem in the context of this study is that Tobin's Q can also be influenced by accounting manipulation. Several researchers found that the change in $\mathrm{Q}$ can be explained in more detail by the variable used to control accounting manipulation rather than the variable used to measure change in the rate of accounting profit. The market value of the firm is the numerator of $Q$ and it partially reflects the value of intangible assets assigned by the investor. Since the tangible asset has some estimated replacement value, it will take the place of the denominator of $Q$ without including the value of the intangible asset that the firm initially invests in. It is therefore assumed that all the revenues generated from the business are derived from tangible assets. This scattered measure of performance depends on the tangible capital of the firm in different degrees. Besides, some researchers who use Tobin's Q do not consider the replacement cost of the tangible asset while calculating the denominator of $\mathrm{Q}$. They utilized the net book value of tangible assets instead of the replacement cost. These kinds of alternate options change the rate of accounting profit hence weakening the reliability of accounting profit.

Villalonga, B. (2019) found that all the ownership structure evaluation models used in the literature are based on the fraction of major shareholding with the most prominent shareholders being the top five shareholders. However, more recent studies have tended to focus on the ownership structure in which shares are owned by management. Management ownership includes the shares owned by managers, the CEO and members of the corporate board. In this situation, there exists a strong bond amongst the shareholders as a result of which the firm is devoid of the agency problem and using the stakeholder theory assumes that all the stakeholders share a common interest. However, this would not be the case if a person does not own enough shares to sit on the board but is a member of the board as a proxy for someone else who has a major shareholding. The interests of these kinds of board members may not align with professional management. It is more likely that their interest will be aligned with those of outside investors who do not sit on the board. Usually in this situation, the insider board members and outsider investors tend to have conflicts of interest. Harold et al., (2001) who studied the relationship between the shares owned by 
important shareholding families and shares owned by management found the fraction to be 0.67 . This positive correlation explains why important family shareholders retain the influence to be represented on corporate boards. Frequently, these family members or their representatives on boards tend to have conflicts of interest with managerial shareholders. Therefore, a high level of managerial ownership is not necessarily reliable since they will not protect the interests of investors.

\section{Hypothesis}

This topic has been heavily researched internationally however in Malaysia, very few studies were conducted to analyze the impact of changing ownership structure on firm performance. It's generally assumed that different ownership structures have differing impacts on firm performance. For instance, in firms with insider ownership structures led by management with little outside influence, outside shareholders may suffer. In family-owned structures the focus is more on organizational culture and trying to maintain the family control instead of organizational growth and firm performance. Firm performance cannot be identified easily as the intention of managers is not clear, whether they are taking optimal decisions or manipulating the earnings (Trejo-Pech et al., 2016). Therefore, based on prior research and results, it will not be wrong to say that ownership structure does not affect firm performance, but the latter is mainly influenced by managerial shareholders and outside shareholders who are the major shareholders. Hence our study proposes the following hypothesis:

$\mathrm{H}$ : Change in variables of ownership affects the firm performance.

\section{Methodology}

\subsection{Data and Sample}

In this study, we collected the data from non-financial companies listed on Bursa Malaysia during the financial period 2011 to 2015. These firms belong to six non-financial business sectors, listed on Bursa Malaysia namely, the Construction sector, the Health care sector, Hotel sector, Properties sector, Utility sector, and Plantation sector. This data does not include the information of financial institutions because it does not meet the criteria for empirical analysis. Bursa Malaysia consists of more than 900 companies. We took 200 listed companies belonging to different business sectors. Financial institutions and firms who haven't provided a complete annual report and those firms whose data is missing for the study variables were not included in our study following previous practice. The ownership structure measures are calculated from the data extracted from companies' financial statements. Investigation of ownership data found that the magnitude of ownership structure varies widely. We used two measures of ownership structure, first the degree of voting rights possessed by shareholders (minimum $5 \%$ of outstanding shares) and second, the degree of ownership possessed by managers (minimum $5 \%$ of outstanding shares). Our hypothesis $\mathrm{H}$ suggests that change in variables of ownership affects the firm performance. This data should be enough to examine our Hypothesis.

We have two types of shareholders, firstly the outside shareholder who possess a minimum of $5 \%$ whom we identify as important shareholder and secondly the insider shareholder whom we identify as managerial shareholder who also possesses a minimum of $5 \%$ of the shares.

Now the most important objective is to identify the systematic relationship between important shareholders and managerial shareholders with firm performance. In order to achieve this objective, we must put both variables into the firm performance equation. As discussed earlier, the relationship between both the variables of study is two-way, i.e. firm performance is not only affected by ownership structure, and equally ownership structure can also be influenced by firm performance. To overcome this problem, we use the econometric model which is based on two simultaneous equations where the dependent variable would be firm performance in the first equation and ownership structure would be the dependent variable in the second equation. This method is estimated using two stages least square and ordinary least square to identify the results arising from using different methods of estimation. The estimation equations are as stated below:

Equation 1

Firm Performance $=$

$$
F P_{t}=\alpha_{1}+\alpha_{t 1} O W S T_{t}+\beta_{t 1} Y_{t}+C_{t 1}
$$

Equation 2

Ownership Structure =

$$
O W S T_{t}=\alpha_{2}+\alpha_{t 2} F P_{t}+\beta_{t 2} U_{t}+C_{t 2}
$$


Where $\mathrm{OWST}_{t}$ is the measure of ownership structure for the th firm, $Y_{t}$ and $U_{t}$ are control variables and Cs are the error variables.

In the above equations, we evaluate the firm performance by using both measures namely Tobin's $\mathrm{Q}$ and the accounting profit rate. We note that Tobin's $Q$ takes both the ratio of the firm's fair value as well as the debt value of the total assets. The ownership variable OWST includes both types of ownership, the important ownership, and the managerial ownership as mentioned earlier. Moreover, we also need to verify whether these different ownership structures significantly affect profitability.

\subsection{Control Variables}

Following on from prior research, there are other also factors that should be measured while evaluating firm performance and ownership structure. These variables should be controlled in order to validate our descriptive results. The following are the control variables

1) SIZE known as the company size considered as the total assets of the company.

2) APR known as the annual accounting profit rate.

3) DEBT known as the increase in debt of the company.

\section{Results}

\subsection{Descriptive Analysis}

Table 1 shows the descriptive analysis for the independent variable firm performance with the dependent variable ownership structure over the period 2011 to 2015 for those companies that are listed on Bursa Malaysia. The descriptive analysis shows positive results. We note that important ownership structure has greater values when compared to managerial ownership structure. The mean value of important shareholders is 1.027 and the mean value for managerial shareholders is 0.519 which is almost half that of the important shareholders. The maximum value for important shareholders is 3.139 and for managerial shareholders is 0.027 . This confirms that most firms in Malaysia have an important shareholder structure. Tobin's Q has all positive values and the mean value is 2.185 which shows that the firms are performing well. Hence, we can conclude that there is a positive relationship between ownership structure and firm performance.

Table 1. Descriptive statistics

\begin{tabular}{lllll}
\hline Variables & Mean & Minimum & Maximum & Standard Deviation \\
\hline Tobin's & 2.185 & 0.161 & 24.557 & 2.462 \\
\hline Important OWST & 1.027 & 0 & 3.139 & 0.548 \\
\hline Managerial OWST & 0.519 & 0 & 2.027 & 0.56 \\
\hline SIZE & $867.2 \mathrm{~K}$ & $5.503 \mathrm{~K}$ & $43,507 \mathrm{~K}$ & $43,448.50 \mathrm{~K}$ \\
\hline APR & 0.062 & -3.839 & 0.714 & 0.319 \\
\hline DEBT & 0.060 & 0 & 0.54 & 0.111 \\
\hline $\mathbf{N}$ & $\mathbf{2 0 0}$ & & \\
\hline
\end{tabular}

\subsection{Correlation Analysis}

Table 2 below shows the correlation analysis between ownership structure and firm performance. Tobin's Q shows an equal relationship between important shareholders and managerial shareholders with a value of 0.019 but in the opposite direction. Important shareholders have a negative value whereas the managerial shareholders have a positive value. Tobin's $Q$ and firm size have a negative relationship with a value of $0.099^{* *}$ but are significant. The firm's rate of profit and Tobin's Q have a positive relationship with a value of 0.014 but it is not significant. Tobin's $\mathrm{Q}$ and firm's debt have a negative relationship but show a high level of significance with a value of $0.277^{* * *}$. Important shareholders have a negative relationship with all the other variables. Managerial shareholders have a negative relationship with firm size but have a positive relationship with accounting profit rate and the firm's debt. Firm size has a positive relationship with the accounting profit rate and the firm's debt. Firm size and firm debt also 
have a significant relationship which shows that as the size of the firm increases, the liabilities of the firm also increase.

Table 2. Correlation analysis

\begin{tabular}{lllllll}
\hline Variables & Tobin's & Important OWST & Managerial OWST & SIZE & APR & DEBT \\
\hline Tobin's & 1 & & & & & \\
\hline Important OWST & -0.019 & 1 & & & & \\
\hline Managerial OWST & 0.019 & $-0.407^{* * *}$ & 1 & 1 & & \\
\hline SIZE & $-0.099^{* *}$ & -0.016 & -0.053 & 0.032 & 1 & \\
\hline APR & 0.014 & -0.056 & 0.048 & $0.106^{* *}$ & 0.000 & 1 \\
\hline DEBT & $-0.277^{* * *}$ & -0.049 & 0.049 & & &
\end{tabular}

Note: $* * * \& * *$ indicate significance at $1 \%$ and $5 \%$ levels, respectively.

\subsection{Regression Analysis}

Table 3 below provides the regression results of Tobin's Q looking at the measure of performance where the ownership structure is managerial while Table 4 below provides the regression results when the ownership structure is based on important shareholders. The results are extracted using the data from 96 firms and comparing it with the ordinary least square and 2 stage least square. Ordinary least square is the estimation model of profitability. We observed that the least one measure of ownership structure is the coordinate on which profitability is dependent. The regression coefficient of important shareholders is also called outsider investor and has a positive value which implies that Tobin's Q has a positive relationship with outside investors. The other ownership structure measure is managerial ownership which also has a positive relationship with Tobin's Q. However, the significance of the coefficient is low when compared with important shareholders. Therefore, the results of regression show that the variable of both types of ownership structure i.e. the important shareholders and the managerial shareholders have a positive sign but statistically, the significance is high for important shareholders and low for managerial shareholders. We also found that the debt ratio has a negative coefficient with Tobin's which shows that debt has a negative impact on firm performance.

Table 3. Regression analysis

\begin{tabular}{|c|c|c|c|c|c|c|c|c|}
\hline \multirow{3}{*}{$\begin{array}{l}\text { Variables } \\
\text { Constant }\end{array}$} & \multicolumn{4}{|c|}{ Ordinary Least Square } & \multicolumn{4}{|c|}{2 Stage Least Square } \\
\hline & \multicolumn{2}{|c|}{ Tobin's Q Eq 1} & \multicolumn{2}{|c|}{$\begin{array}{l}\text { Managerial } \\
\text { Shareholding Eq } 2\end{array}$} & \multicolumn{2}{|c|}{ Tobin's Q Eq 1} & \multicolumn{2}{|c|}{$\begin{array}{l}\text { Managerial } \\
\text { Shareholding Eq } 2\end{array}$} \\
\hline & 0.174 & $(0.318)$ & 0.442 & $(6.969)$ & 0.376 & $(0.642)$ & 0.214 & $(0.833)$ \\
\hline $\begin{array}{l}\text { Important } \\
\text { OWST }\end{array}$ & 1.372 & 3.586 & & & 1.401 & $(3.641)$ & & \\
\hline $\begin{array}{l}\text { Manageria } \\
\text { l OWST }\end{array}$ & 0.297 & $(1.757)$ & & & 0.260 & $(1.901)$ & & \\
\hline SIZE & & & -0.00003 & $(-0.150)$ & & & -0.00004 & $\begin{array}{l}(-0.194 \\
)\end{array}$ \\
\hline APR & & & 0.045 & $(2.680)$ & & & 0.134 & $(1.331)$ \\
\hline DEBT & -3.247 & $(-1.964)$ & -0.149 & $(-0.389)$ & -3.051 & $(-1.826)$ & 0.043 & $(0.084)$ \\
\hline Adj $R^{\wedge} 2$ & 0.179 & & 0.133 & & & & & \\
\hline
\end{tabular}


Table 4. Regression analysis

\begin{tabular}{|c|c|c|c|c|c|c|c|c|}
\hline \multirow{3}{*}{$\begin{array}{l}\text { Variables } \\
\text { Constant } \\
\end{array}$} & \multicolumn{4}{|c|}{ Ordinary Least Square } & \multicolumn{4}{|c|}{2 Stage Least Square } \\
\hline & \multicolumn{2}{|c|}{ Tobin's Q Eq 1} & \multicolumn{2}{|c|}{$\begin{array}{l}\text { Important } \\
\text { Shareholding Eq } 2\end{array}$} & \multicolumn{2}{|c|}{ Tobin's Q Eq 1} & \multicolumn{2}{|c|}{$\begin{array}{l}\text { Important } \\
\text { Shareholding Eq } 2\end{array}$} \\
\hline & 0.174 & $(0.318)$ & 0.850 & (14.303) & 0.376 & $(0.642)$ & 0.486 & $(1.777)$ \\
\hline $\begin{array}{l}\text { Important } \\
\text { OWST }\end{array}$ & 1.372 & 3.586 & & & 1.401 & $(3.641)$ & & \\
\hline $\begin{array}{l}\text { Managerial } \\
\text { OWST }\end{array}$ & 0.297 & $(1.757)$ & & & 0.260 & $(1.901)$ & & \\
\hline SIZE & & & & & -0.00003 & $(-0.150)$ & -0.00005 & $(-1.567)$ \\
\hline APR & & & 0.045 & $(2.680)$ & & & 0.134 & $(1.331)$ \\
\hline DEBT & -3.247 & $(-1.964)$ & 0.155 & $(0.429)$ & -3.051 & $(-1.826)$ & 0.544 & $(1.018)$ \\
\hline $\operatorname{Adj} R^{\wedge} 2$ & 0.179 & & 0.204 & & & & & \\
\hline
\end{tabular}

\section{Conclusion}

This study looked at the relationship between ownership structure and firm performance in various ways. Our objective was to examine whether a change in variables of ownership structure affects firm performance in the Malaysian business market. The data verified our hypothesis by using Tobin's Q firm performance measure and accounting profit rate with two ownership concentrations namely important ownership and managerial ownership. Important ownership refers to outsider ownership concentration whereas managerial ownership refers to insider ownership concentration.

Our empirical data based on 200 Malaysian listed companies used a total of 1000 observations over the period 2011 to 2015. The empirical analysis found that both ownership structure and Tobin's Q have a positive and linear relationship. Tobin's Q was positively influenced by both types of ownership structure, namely important shareholders and managerial shareholders. Eventually however, it depends which party possessed the higher degree of shareholding be it insider or outsider, as both parties will tend to manage the firm in a better manner since they possessed control over the firm. This study finds that the measure of ownership structure is positively predicted by profitability. It also suggests that the relationship of ownership-profitability would be biased, if measured by the coefficient of single equation model as it is unable to account for the complexities in ownership interest. Thus, the Malaysian data reveals the positive relation of ownership structure with profitability. Moreover, the good firm performance leads to the increase in stock value which ultimately increases the share ownership of both kinds of shareholders. Here it is important to note that prior studies found that firms with managerial ownership structures tended to be run more effectively when compared to firms run by outsiders leading to better performances overall.

We would suggest the further research related to development and estimation of non-linear model. Although some authors previously used non-linear single equation model to test the relationship of managerial ownership and profitability, they were unable to monitor the endogeneity of ownership structure. Hence our suggestion to consider both the endogeneity and non-linearity while developing a non-linear equation model with non-monotonic relationship.

\section{References}

Abdallah, A. A. N., \& Ismail, A. K. (2017). Corporate governance practices, ownership structure, and corporate performance in the GCC countries. Journal of International Financial Markets, Institutions and Money, 46, 98-115. https://doi.org/10.1016/j.intfin.2016.08.004

Al-Malkawi, H. A. N., \& Pillai, R. (2018). Analyzing financial performance by integrating conventional governance mechanisms into the GCC Islamic banking framework. Managerial Finance, 44(5), 604-623.

Al-Matari, E. M., Al-Dhaafri, H. S., \& Al-Swidi, A. K. (2019). The Effect of Government Ownership, Foreign Ownership, Institutional Ownership, and Audit Quality on Firm Performance of Listed Companies in Oman: A 
Conceptual Framework. In Proceedings of the Second International Conference on the Future of ASEAN (ICoFA) 2017 (Volume 1, pp. 585-595). Springer, Singapore.

Al-Thuneibat, A. (2018). The Relationship between the Ownership Structure, Capital Structure and Performance. JABM Journal of Accounting-Business \& Management, 1(25), 1-20.

Bendickson, J., Muldoon, J., Liguori, E. W., \& Davis, P. E. (2016). Agency theory: background and epistemology. Journal of Management History, 22(4), 437-449. https://doi.org/10.1108/JMH-06-2016-0028

Boateng, A., Liu, Y., \& Brahma, S. (2019). Politically connected boards, ownership structure and credit risk: Evidence from Chinese commercial banks. Research in International Business and Finance, 47, 162-173.

Chen, H. M., Lin, C. H., Kao, T. C., \& Wei, T. J. (2016). The Effects of Corporate Governance on Idiosyncratic Risk: Evidence from Financial Institutions in Taiwan. Journal of Finance, 4(2), 17-24.

Chrisman, J. J., Fang, H., Kotlar, J., \& De Massis, A. (2015). A note on family influence and the adoption of discontinuous technologies in family firms. Journal of Product Innovation Management, 32(3), 384-388.

Feldman, E. R., Amit, R., \& Villalonga, B. (2019). Family firms and the stock market performance of acquisitions and divestitures. Strategic Management Journal, 40(5), 757-780.

Galego, A., Mira, N., \& Silva, J. V. (2019). Ownership, productivity and firms' life-cycle. European Journal of Family Business, 8(2), 139-150. https://doi.org/10.24310/ejfbejfb.v8i2.5228

He, W., \& Kyaw, N. A. (2018). Ownership structure and investment decisions of Chinese SOEs. Research in International Business and Finance, 43, 48-57. https://doi.org/10.1016/j.ribaf.2017.07.165

Hoang, L. T., Nguyen, C. C., \& Hu, B. (2017). Ownership structure and firm performance improvement: Does it matter in the vietnamese stock market?. Economic Papers: A Journal of Applied Economics and Policy, 36(4), 416-428. https://doi.org/10.1111/1759-3441.12185

Kamardin, H., Latifa, R. A., \& Mohdb, K. N. T. (2016). Ownership Structure and Firm Performance in Malaysia. In International Conference on Accounting Studies, Langkawi, Kedah.

Mukhopadhyay, J., \& Chakraborty, I. (2017). Foreign institutional investment, business groups and firm performance: Evidence from India. Research in International Business and Finance, 39, 454-465.

Paniagua, J., Rivelles, R., \& Sapena, J. (2018). Corporate governance and financial performance: The role of ownership and board structure. Journal of Business Research, 89, 229-234.

Rashid, A. (2016). Managerial ownership and agency cost: evidence from Bangladesh. Journal of Business Ethics, 137(3), 609-621. https://doi.org/10.1007/s10551-015-2570-z

Sadiq, M., \& Othman, Z. (2017). Earnings manipulations in politically influenced firms. Corporate Ownership \& Control, 15(1), 65-71. https://doi.org/10.22495/cocv15i1art6

Sadiq, M., Othman, Z., \& Ooi, C. K. (2019). A Study of Interaction Effects of Political Influences and Earnings Management on Organisational Performance. Asian Economic and Financial Review, 9(5), 642.

Shahveisi, F., Khairollahi, F., \& Alipour, M. (2017). Does ownership structure matter for corporate intellectual capital performance? An empirical test in the Iranian context. Eurasian Business Review, 7(1), 67-91.

Trejo-Pech, C. J., Weldon, R. N., \& Gunderson, M. A. (2016). Earnings management through specific accruals and discretionary expenses: Evidence from US agribusiness firms. Canadian Journal of Agricultural Economics/Revue Canadienne D'agroeconomie, 64(1), 89-118. https://doi.org/10.1111/cjag.12063

Villalonga, B. (2018). The impact of ownership on building sustainable and responsible businesses. Journal of the British Academy, 6(s1), 375-403. https://doi.org/10.5871/jba/006s1.375

Villalonga, B. (2019). Ownership structure and corporate performance: Looking back and looking forward. Journal of Corporate Finance, 58, 64-67. https://doi.org/10.1016/j.jcorpfin.2019.04.005

Wahba, H., \& Elsayed, K. (2015). The mediating effect of financial performance on the relationship between social responsibility and ownership structure. Future Business Journal, 1(1-2), 1-12.

Wamba, S. F., Gunasekaran, A., Akter, S., Ren, S. J. F., Dubey, R., \& Childe, S. J. (2017). Big data analytics and firm performance: Effects of dynamic capabilities. Journal of Business Research, 70, 356-365.

Zandi, G., Sadiq, M., \& Mohamad, S. (2019). Big-Four Auditors and Financial Reporting Quality: Evidence from Pakistan. Humanities \& Social Sciences Reviews, 7(2), 369-375. https://doi.org/10.18510/hssr.2019.7243 